\title{
Canada, Empire and Indigenous People in the Americas
}

\author{
Todd Gordon York University
}

\begin{abstract}
Résumé
Le présent article avance que le Canada est une puissance impériale dans l'ordre mondial, fait dont ne tiennent pas assez compte les notions du Canada comme une riche dépendance ni les arguments requérant un projet visant à défendre la souveraineté du pays. Or, au cœur du projet d'État canadien, tant par le passé que dans ses manifestations contemporaines, existe un programme d'accumulation par dépossession dont les nations indigènes sont une cible privilégiée. À l'heure du néolibéralisme, le capital canadien cherche, avec l'appui de l'État, de nouveaux espaces d'accumulation, tant au pays qu'à l'étranger, notamment en Amérique latine - processus où les terres indigènes et la main d'œuvre représentent des atouts clés. En réaction, au lieu de défendre la souveraineté canadienne, la gauche doit élaborer une analyse résolument anti-impérialiste du rôle du Canada dans l'économie mondiale. Pour illustrer les dynamiques impérialistes qu'il cerne, l'article s'appuie sur un exemple particulièrement important : celui des politiques et des stratégies de l'industrie minière canadienne.
\end{abstract}

\begin{abstract}
This article argues that Canada is an imperial power in the global order, and that more traditional notions of Canada as a rich dependency or arguments that call for a project to defend Canadian sovereignty fail to properly account for this. Central to the Canadian state project, both in its historical and contemporary manifestations, is an agenda of accumulation by dispossession, in which Indigenous nations are a central target. In the period of neoliberalism, Canadian capital, facilitated by the state, is searching out new spaces of accumulation in Canada and abroad, particularly in Latin America, and Indigenous land and labour are crucial to its success. Instead of defending Canadian sovereignty, the Left must respond by developing a sharp anti-imperialist analysis of Canada's role in the global economy. This article will draw on the policies and strategies of Canada's mining industry, which is a powerful actor at home and abroad, as one important example of the imperialist dynamics it is tracing.
\end{abstract}




\section{Introduction}

As the United States occupies Iraq, threatens the likes of Iran, Syria and North Korea with invasion, and increases its rhetoric against left-leaning South American politicians, it has become an increasing focus of anti-imperialist analysis and organizing. This analysis and organizing, of course, is much needed, given the threat U.S. foreign policy poses to international peace and security and the well being of billions of people around the world. But for many Canadians on the Left, the focus on U.S. foreign policy has unfortunately and unnecessarily drawn their attention away from their own government's imperialist policies. Canada, it is mistakenly assumed by many Canadian leftists, is not an imperial power nor has it an imperial ambition, despite its history within its own borders, its status as an advanced capitalist country, and its recent role in the overthrow of Haiti's democratically elected president, Jean-Bertrand Aristide (Engler and Fenton, 2005). These assumptions pervade NGOs, the New Democratic Party, and the Canadian political economy literature. This article challenges these assumptions, offering an anti-imperialist perspective on Canada that will hopefully add to the current literature and open up further discussion on the Left about the character of the Canadian state. Canada, it will be argued, is an imperial power in the global order - certainly not as powerful as the U.S., but an imperial power nonetheless - and the increasing control of Indigenous people and land is central to its political and economic interests, indeed is at the core of the Canadian state project both within and outside of its borders. The Canadian state, to borrow a term from Harvey (2003), is systematically engaging in a strategy of "accumulation by dispossession" in which Indigenous peoples and their land are important targets.

Advancing an anti-imperialist analysis of Canada from this angle properly situates the central location of Indigenous people across the Americas in our understanding of the Canadian state's and capital's accumulation strategies. Simply put, Indigenous land and labour is absolutely key to Canadian capital's success in Canada and the rest of the Americas, particularly in the mining and resource sectors. Thus any meaningful analysis of the development of the Canadian state must be framed by its colonial ambition toward Indigenous peoples, and the latter's historic resistance to being subordinated to capitalist imperatives. Focusing on the Canadian state's policy towards Indigenous people also highlights the internal relationship between its colonial character both within Canadian borders and increasingly beyond those borders.

This anti-imperialist analysis also forces us to consider more deeply the true character of the Canadian state. Contemporary policies towards Indigenous people, for instance, as they expand from Canada to other parts of the Americas, are not new; they are part of an ongoing legacy of colonialism out of which Canada was born and the Canadian state developed. From its outset, in other words, the Canadian state has been imperialist. It is not simply a matter, then, of a particular set of actors having control within state 
institutions at a particular moment or of easily rectified policy choices. The Canadian state project is by definition imperialist, as the negation of the self-determination of Indigenous nations and the occupation of their land is a premise of its existence; and this agenda is intensifying across the Americas in the period of neoliberalism.

This presents a serious challenge to the Canadian political economy literature, which can be critical of Canadian policy but which seldom problematizes the existence of the Canadian state itself or identifies it as imperialist. The institutionalist foreign policy literature, for example, tends to treat Canadian foreign policy since the late $1980 \mathrm{~s}$ as simply a matter of bad policy decisions shaped by specific institutional actors without whom Canada would pursue more progressive policy - in Pratt's (1994) words, a "humane internationalism" - rather than driven by the logic of capitalist expansion underlying advanced capitalist countries and their relation with one another and the South. The Canadian dependency school, many of whose contributors identify as socialist, also fails to properly account for the Canadian state as an imperialist centre, since it considers Canada a subordinate power to the U.S. with a weak bourgeoisie and embroiled in a relation of dependency in a manner not dissimilar to developing nations. As a result, its primary political goal is 'sovereignty' from the U.S., and it sees the state playing a central role here as a potentially progressive space that can be mobilized to break the yoke of dependant relations. But when we consider the history of the colonies of Indigenous nations at home and the appropriation of their land abroad, and Canadian capital's increasing penetration of foreign economies, the political goal of the Left must be a clear and sharp break from the state and any 'sovereignty' project.

Although Canadian political-economic interests are global, I am going to focus here on the Americas in particular. A more thorough study of Canada's global activities is beyond the scope of this article, while Canada's imperialist activities are particularly salient in the Americas, where the Canadian state and capital, as an advanced capitalist component of a broader long-term trend of hemispheric integration, are playing an increasingly prominent role. ${ }^{1}$ At the same time, despite Canadian capital's prominence in a number of sectors in the global economy, one where the tension with Indigenous people is especially sharp, it is worth noting, is in mining. Canadian mining companies are some of the most powerful in the global industry, and as they have expanded their interests abroad over the last decade or so, they have quickly earned themselves a very negative reputation from Indigenous nations, trade unionists, and environmentalists outside of Canada. While this article is not about the Canadian mining industry per se, it will nevertheless draw on some of their policies as a useful and concrete example of the broader dynamics of Canadian imperialism I am seeking to trace.

${ }^{1}$ Canada's deepening integration with the U.S. is an important issue, particularly as it relates to the role of North America in the global order in competition with the European Union and China. But its consideration is beyond the scope of this article, which seeks to focus attention instead on Canada's own, and often overlooked, imperialist ambition, which at present cannot simply be reduced to its integration with the U.S. 


\section{Imperialism and Accumulation by Dispossession}

Before turning our attention to Canada specifically, it is necessary to say a few things about imperialism more generally. Canada obviously does not exist in a vacuum; it is an advanced capitalist state within a hierarchy of nations operating within the global capitalist economy, and so its imperialist character needs to be situated within the broader dynamics of global capitalism and the relations between countries of the Global North and those of the Global South.

Since the emergence of neoliberal globalization, Marxist analyses of imperialism have gained renewed vigour, and this has increased even more so following 9-11 and the U.S.'s declaration of its 'war on terror'. Now, the objective here is not to cover the different debates amongst Marxists about the most suitable theory of imperialism; those debates continue to take place elsewhere, in various magazines and journals with which many readers are likely familiar, and so it is not necessary to rehash them here. ${ }^{2} \mathrm{I}$ am, in any case, most sympathetic to the theoretical formulations of David Harvey, expressed in his concept of accumulation by dispossession, which I think, and will indeed attempt to show, offers the most insight into the historical and contemporary practices of Canadian state power (Harvey, 2003: 1999). One of the advantages Harvey's analysis offers over others, in my view, is that it does not reduce imperialism to an institutional feature of the capitalist state or to a reckless Presidential regime and its insatiable thirst for oil. While a given set of actors, such as the so-called 'neo-cons' in the U.S. no doubt shape imperialist policy according to their (or the section of the ruling class they represent) predilections, imperialism, as Harvey stresses, drawing on Marx's Capital, is a dynamic at the heart of capitalist social relations. Imperialism, in other words, will not disappear with the disappearance of George W. Bush and co. or with an institutional rearrangement of the capitalist state, just as it existed before Bush Jr. and during earlier configurations of capitalist state power. Imperialism's form may change in different historical periods, of course, but it is nonetheless rooted in the logic of a socio-economic system that is driven by the competitive pursuit of profit based on the exploitation of labour, and which is subsequently prone to overaccumulation. This suggests, furthermore, that it is not the preserve of a single superpower either, but underlies the dynamics of other advanced capitalist economies as well, and perhaps even some economies outside the core, though richer nations are obviously in a much better position to engage in imperial practices than weaker ones. The concept of accumulation dispossession also importantly stresses, as I will note in a moment, the violent character inherent to imperialist practices, even outside of the period of formal empires and inter-imperial war.

Imperialist state power, then, is an expression of the contradictory character of capitalist accumulation. As Harvey (2003: 64) argues, in a context of overaccumulation, "If systemwide devaluations (and even destruction) of capital and of labour power are not to follow,

${ }^{2}$ The Socialist Register, Historical Materialism, Monthly Review, and Canadian Dimension, among others, have all featured discussions on imperialism, alongside a number of books recently published on the subject. 
then ways must be found to absorb these surpluses. Geographical expansion and spatial reorganization provide one such option." Capital, facilitated by its respective state, whose aim is to ensure the expanded reproduction of capitalist social relations, pursues a spatial fix to resolve the systematic crisis of overaccumulation. New geographical regions are sought to absorb the existing surpluses of capital and avoid their devaluation, for instance, while flagging profitability can be improved by accessing cheap labour and raw materials in these areas. In effect, fresh spaces of accumulation are established as capitalism penetrates new territories, creating "a world after its own image" (Marx, 1995: 13), or as older colonial spaces are radically transformed in the interests of a new accumulation strategy. But the creation of new spaces of accumulation is not a smooth or innocuous process; it inevitably involves the forceful and violent reorganization of peoples' lives as they are subordinated to the fancy of capital. Resources and land, which may have been used for subsistence living, must be appropriated for capital's use, for example, and capitalist social relations must be imposed on reluctant populations, a process resisted time and again by people across different cultures seeking to avoid - often by whatever means available - the exploitative and alienating experiences of work under capitalism (McNally, 2002: 65). All of this is typically backed up by military and/or paramilitary force or its ever-present threat.

This is in fact the process Marx refers to as "primitive accumulation" in his description of the violent and bloody emergence of capitalist social relations in seventeenth and eighteenth century England in Capital. But the limit of Marx's analysis of "primitive accumulation" in Capital, Harvey (2003: 74) argues, expressed in the use of the descriptor "primitive", is that it "relegate[s] accumulation based upon predation, fraud, and violence to an 'original stage' that is considered no longer relevant or, as with Luxemburg, as being somehow 'outside of' the capitalist system." Because, however, all the features Marx describes are still actually a central part of capitalist accumulation, "[a] general reevaluation of the continuous role and persistence of the predatory practices of 'primitive' or 'original' accumulation within the long historical geography of capital accumulation is ... very much in order" (Harvey, 2003: 74). This "primitive accumulation" - which Harvey more accurately refers to as accumulation by dispossession - is a key modus operandi of imperialism, and as such is "omnipresent in no matter what historical period and picks up strongly when crises of overaccumulation occur in expanded reproduction, when there seems to be no other exit except devaluation" (Harvey, 2003: 76).

It is also important to note here that this imperialist process is very racialized. While imperialism is driven by the contradictions of capitalist accumulation, it is also rooted in the production and mobilization of deeply held racist ideology, which serves to justify conquering people and subordinating them to imperialisms' whims by de-humanizing them. By constituting the colonized as racially inferior, imperialists are able, on the one 
hand, to present themselves as partaking in a progressive civilizing mission - that colonization is as much for the colonized as it is for the imperialists - and, on the other, to ideologically justify violence and repression should the colonized act 'irrationally' and resist (see McNally, 2002, for an excellent discussion of race and imperialism).

The Canadian state's predatory historic relationship with Indigenous people provides a sharp example of the dynamics of accumulation by dispossession, and serves as a potent reminder of Canada's imperialist history. The expansion of the capitalist state west of Ontario, for instance, was opposed by the Métis and other Indigenous nations, and was made possible only after the military defeat of the national liberation struggle in the then -Northwest Territories (the so-called Riel Rebellion). Indeed, the Royal Northwest Mounted Police, the forerunner to the Royal Canadian Mounted Police (RCMP), and much used tourist symbol of Canadian identity, was formed specifically to force Indigenous people to submit to Canadian authority. Military force, or the ever present threat of its application, was used to appropriate unceded Indigenous land throughout the country while many Indigenous nations undoubtedly felt compelled to sign treaties because of the imbalance of force between them and the Canadian state. On top of this, many of the Indigenous nations that did sign treaties typically did so under a different understanding about the implications of the agreements - that, for example, they were not forsaking the exclusive right to their land or their political sovereignty - than that held by their treaty partner, and despite even this Canada has still systematically ignored much of its treaty obligations to First Nations across the country (Teillet, 2005).

Central to accumulation by dispossession, Canadian-style, is the 1876 Indian Act. Although its international legacy is not heralded as much by Canadians as, say, our 'peacekeeping' status, the Indian Act nevertheless had a formative influence on racist laws in other parts of the British colonialies that were designed to dominate indigenous peoples, including South African apartheid (Hall, 2003: 498-499). The Canadian state established, through the Indian Act and successive Indian Affairs ministries that have traditionally been subsumed under various economic ministries like 'Mines and Resources' or 'Northern Development' (Satzewich and Wotherspoon, 1993: 36), a nexus of administrative and legal measures that constitute "a totalitarian 'cradle-to-grave' set of rules, regulations and directives to manage Native lives" (Stasiulis and Jhappan, 1995: 114). While the Canadian state grudgingly granted reservation land to many (though not all) First Nations, due largely to Indigenous peoples' absolute refusal to prostrate themselves to Canadian colonialism, it did so in such a way as to undermine Indigenous self-sufficiency and provide itself with the opportunity for closer surveillance of colonized communities. Framed by a white supremacist conceit that legitimizes the state's constitution of Indigenous people as uncivilized and therefore in need of guardianship by white people, the Act and the practices surrounding it have been central to the state's strategy to 
undermine Indigenous self-determination and self-sufficiency, and impose market relations on them (Adams, 1999, 1989; Satzewich and Wotherspoon, 1993). Under the Indian Act, the state forced First Nations onto reservations, arrogated to itself total political authority over reserve communities, and imposed the band council governing system on them in place of traditional decision-making structures. To this day, in fact, the Minister of Indian Affairs still has the authority to overturn band council decisions. Meanwhile, the Indian Act also established special Indian Agents who were charged with closely monitoring reserve communities and using Pass Laws (until 1951) to inhibit Indigenous movement off reservations (Stasiulis and Jhappan, 1995). Since growing numbers of Indigenous people from the late nineteenth century onwards were engaged in at least parttime wage labour off-reserve in many parts of the country, it is obvious that a key aim of the Pass Laws was to keep them from pursuing traditional forms of subsistence off of statedesignated reserve land, even if the reserve land was unsuited to support an entire community, as it often was by state design. ${ }^{3}$ Governments have also exploited the economic vulnerability of Indigenous communities in other ways in order to force their reluctant members into market relations, such as by cutting off social benefits to reservations during harvest season when their cheap labour was especially needed in the agricultural industry (Laliberte and Satzewich, 1999; on wage labour see also Simmons, 1999; and High, 1996; Knight, 1996; and Elias, 1988). At the same time, gift-giving festivals, such as the Potlatch, were outlawed by the Act from 1880 to 1951 . These festivals promoted, on the one hand, economic redistribution, which constituted a barrier to the more competitive capitalist ethic and to dependence on market relations, and, on the other, traditional aboriginal leadership structures (Stasiulis and Jhappan, 1995).

Moral training and the imposition of British values were also actively pursued in the effort to establish Indigenous subservience to Canadian authority and the demands of capitalist accumulation. Wives of missionaries, moral reformers, and governmental officials "sought to destroy the fabric of First Nations life" through welfare policies, and the reproduction of British gender norms through domestic training and teaching Indigenous women "proper" housekeeping and food production (Satzewich and Wotherspoon, 1993: 82). One of the harshest examples of this strategy was the forceful removal of Indigenous children from their families and their subsequent placement in residential schools where they were isolated from their communities and its traditions, language and customs, and subjected to systematic physical and sexual abuse. ${ }^{4}$

\section{Imperialism in the Age of Neoliberal Globalization}

With the emergence of neoliberalism we are witnessing a new phase of imperialism. Neoliberalism is a ruling class response to the crisis of overaccumulation in the advanced

${ }^{3}$ Traditional subsistence has often been used as a form of resistance to complete dependence on the market.

${ }^{4}$ The Assembly of First Nations' website, www.afn.ca has a good archive of material on residential schools and their legacy. 
capitalist economies of the 1970 s, aimed at the restoration of profitability through the aggressive restructuring of social relations. But the profitability crisis also spurred an intensification of the geographical expansion of capital from the Global North. The advanced capitalist states, with the United States providing leadership, has successfully sought out new spaces of accumulation, or dramatically reorganized in the Global North's own interests older colonial ones, to absorb the North's surpluses and boost flagging profitability. For instance, as is well reported, through their control of international organizations, such as the International Monetary Fund (IMF) and the World Bank, countries of the Global North have been able to submit countries of the South to their global agenda of political and economic restructuring. With the debt crisis of the early 1980s as an initial springboard, the IMF and World Bank have managed to open up the economies of, and impose drastic bouts of neoliberal restructuring on, developing nations through its debt management practices. The structural adjustment policies associated with these practices entail the removal of trade and investment barriers for capital from the North, cuts to public services and subsidies to local producers and consumers, and the privatization of formally communal land, among other things. Corresponding to the emergence of structural adjustment as a strategy for gaining access to the economies of the South, furthermore, are free trade agreements, which are also aimed at codifying neoliberalism and investment rights of capital from the North in developing nations. Rich nations, of course, present neoliberal globalization with the shiniest of glosses, as involving necessary measures to help the developing countries to help themselves and become internationally competitive (establish 'macro-economic stability'), and almost never take responsibility for its demonstrative failures - there's always more red tape, more government to be cut. Despite this, the direct impact of structural adjustment and free trade on the economies of the South and its inhabitants has been nothing short of tragic. ${ }^{5}$

Not only has neoliberal globalization led to a massive transfer of wealth from the South to the North via debt repayments that were compounded by the extremely high interest rates of the 1980s, but multinationals from the North have gained unprecedented access to the economies and natural resources of developing countries, dispossessing billions of people of these resources in the process. Despite the rhetoric of free trade heard from neoliberal globalization's advocates, what really has 'defined the era of globalization' is not trade at all, McNally argues (2002: 38), but "large-scale foreign direct investment (FDI)." This trend is important to our understanding of the global economy, since FDI involves the long-term investment by corporations in foreign countries and, potentially, increasing influence over their economies. In the last two decades, FDI has increased at a phenomenal pace, growing by over 200 percent from the late 1980 s to the mid-1990s alone, and in the age of neoliberal globalization FDI has increasingly involved fixed investments in factories, mines, natural resources, communication systems, and services,

${ }_{5}^{5}$ More detailed analysis of the reorganization of global capitalism can be found in Harvey (2003), Gowan (1999), and Bonefeld (1993). 
whereas previously FDI was more liquid in nature (McNally, 2002: 38). According to McNally, "[b]y 1998, total outward foreign direct investment hit a record level of $\$ 649$ billion in a single year", and some estimates suggest it reached the $\$ 1$ trillion mark in 2000 (McNally, 2002: 38). Further, while much of this investment takes place between rich nations, FDI from the Global North into the South has grown significantly since the 1990s and makes up an increasing percentage of international totals (McNally, 2002). It is this economic trend, McNally stresses, that lies behind international economic pacts like the failed (and atypically honestly named) Multilateral Agreement on Investment, the North American Free Trade Agreement (NAFTA), and the proposed Free Trade Area of the Americas; international bodies like the World Trade Organization; and the structural adjustment policies pursued by the IMF and World Bank. ${ }^{6}$ And bound up with this new regime of investor rights, Harvey (2003) notes, are new means of accumulation by dispossession. Entirely new areas of investment are being opened by corporations and their governments from the North in their insatiable drive for new ways to increase profits: "agreements" on intellectual property rights, patenting of genetic resources, and the commodification of cultural forms are all examples of this trend in the game of capitalist adventure where practically everything - including water - can be privately owned.

The other significant trend shaping neoliberal globalization and the new phase of imperialism is the increase in proletarianization - of people with no other means of survival but to sell their ability to labour on the market for a wage. This proletarianization, McNally (2002) observes, has been a central feature of capitalism since its emergence 500 years ago, but the dynamics of neoliberal globalization have intensified this process, as a billion more direct producers have been separated from their means of production over the last two decades and forced into market relations in order to attempt to eke out a living. Neoliberal globalization involves, in effect, another massive wave of enclosures. A number of things have converged "to push millions of people off the land and into the labour market ... contributing to a growing pool of cheap labour available around the world" (McNally, 2002: 71). These things include: agricultural protectionism from the North which makes it impossible for small-scale farmers in the South to compete on the international market, the privatization, appropriation and pollution of indigenous land and natural resources by corporations from the North, narco-terrorism sponsored by the U.S. and other rich nations, and massive infrastructure projects (such as dam building) promoted by the World Bank. Business and government leaders have historically always portrayed the violent subordination of people to the labour market and capitalist exploitation as a charitable attempt to lift people out of poverty, and they act no differently today: World Bank annual progress reports on structural adjustment on various Latin American economies, for instance, invariably stress the need for the rural poor to enter formal market relations as a necessary measure to extricate themselves from poverty

${ }^{6}$ Chapter 11 of NAFTA is an excellent example of the codification of investor's rights in trade agreements. 
caused by attempting to live solely off the land. ${ }^{7}$

\section{Neoliberalism and Empire at Home}

The development of neoliberalism in Canada has led to a renewed intensification of accumulation by dispossession directed against Indigenous people. Neoliberalism is a response to the profitability crisis of the 1970s and the subsequently intensified global competition, and involves the recomposition of labour markets and the search for new areas of accumulation. Within Canada, Indigenous land and labour figures centrally within the ruling class's neoliberal designs: the success of neoliberalism is in large measure contingent on the increased penetration of Indigenous land and commodification of their labour power. While, as I have argued, accumulation by dispossession has been a key historical moment in the development of Canada, because of their resistance to the Canadian state project, large layers of the Indigenous population have nevertheless not been fully integrated into market relations, and considerable portions of their land, much of it resource-rich, have not been subject to capitalist development. The frontier of capitalist expansion, in the eyes of the state and capital, still has significantly further to go in Canada.

In a context in which, on the one hand, capital is aggressively pursuing a cheaper and more flexible labour force as part of its agenda of neoliberal restructuring, and, on the other, the non-Indigenous Canadian-born population's fertility rates remain low (Ministry of Industry, 2003), Indigenous labour has become highly valued. This is particularly the case, furthermore, in the resource industries where investments are typically located in rural areas in close proximity to reserve communities, which we will discuss in a little more detail in a moment in relation to mining. In any case, as Simmons (1999: 136-137) argues, dispossessed and/or desperate Indigenous people, subject to a systematic discrimination expressive of the deeply rooted racist character of Canada, offer a potentially significant pool of cheap labour. Indeed, the proletarianization of Indigenous people, and the latter's resistance to this project, is a key concern of the government's policy towards them. Laliberte and Satzewich (1999: 2), in their study of the agro-industry in Alberta, note that, "[t]he proletarianization of Native people was (and is) a well known objective of the Indian Affairs Branch of the federal government." Reservations were organized, and are still viewed by government, they maintain, as a pool of cheap reserve labour (1999: 2). This focus on the labour potential of Indigenous people seems to have sharpened since the emergence of neoliberalism. Peters and Rosenberg (1995: 77) observe, for instance, that labour force issues relating to Indigenous people, including their consistently lower participation rates than non-Indigenous Canadians, has become a very consistent theme in Indian Affairs' studies since the 1980s. Indian Affairs studies commonly note the significant growth rates of the Indigenous population, which are much higher than the non-Indigenous population. But not only is their growth rate significantly

${ }^{7}$ The mainstream development literature employs the nice euphemism, "livelihood diversification", to describe the process of proletarianization it supports. See, for instance, Dolan (2004). 
higher, more importantly their working-age population (typically measured at $15 \mathrm{yrs}$ of age and older) is increasing at a much faster pace. As one study (Ministry of Indian Affairs and Northern Development, 2002a) stresses, "The Aboriginal workforce will grow at twice the rate of the total Canadian labour force in the next ten years". ${ }^{8}$

Promoting the market integration of First Nations is a pre-occupation of the Canadian government, matched only by the government's promotion of resource development in Indigenous communities. Although the government's efforts here are presented to Indigenous people and the public more generally with a charitable veneer - 'economic development', 'sustainability' and 'self-government' are typical buzzwords in government literature - and in the interests of the colonized first and foremost, the reality remains that 'economic development' of Indigenous communities is premised on the negation of their self-determination. The Canadian state's and bourgeoisie's efforts to create a world after its own image in Indigenous communities requires, after all, the exploitation and degradation of natural resources essential to the social, cultural and economic sustainability of their nations, and the mobilization of their labour away from traditional community practices towards the capitalist market. Not surprisingly, then, and to the chagrin of the state and capital, large layers of the Indigenous population continue to resist their full absorption into capitalist relations. As government documents salaciously note the potential Indigenous labour supply and the wealth of resources on Indigenous land, so too do they often reflect on the difficulties of getting Indigenous people to sell their labour for a wage or willingly permit the penetration of their communities by resource companies. Indeed, to the extent Indigenous people, especially on reserves, participate in the wage economy, it is often to support traditional subsistence activities (Simmons, 1999; High, 1996; Peters and Rosenberg, 1995). A typical attitude towards the formal economy among Indigenous groups is collectively expressed, for instance, by an Ojibwa community who, according to Peters and Rosenberg (1995: 92), stress that it contradicts their values, and that they do "not consider the exchange [of their labour] for money a satisfactory arrangement because it meant that workers were not partners in joint-labour exchanges, but 'slaves'." The continued resistance by Indigenous people to market relations and capitalist development on their land are intimately bound up with one another, as the loss of land to development invariably threatens traditional subsistence practices which can serve as a buffer to the waged economy, and express their ongoing struggle for selfdetermination - a struggle which marks the limits of capitalist expansion in Canada. In response, as I will show, the Canadian state is engaged in a sustained effort to dispossess Indigenous people of their land, ranging from legal manipulations to outright violence, as the pressures of capitalist expansion over the last two decades have intensified, indeed militarized, the colonial conflict between Canada and Indigenous nations.

\footnotetext{
${ }^{8}$ These labour force themes can be found in Ministry of Indian Affairs and Northern Development (2002b, 2001, 1997a, 1997b). It is worth noting that this is also the context in which the demand for immigration has increased, while the government makes it increasingly difficult for immigrants to get permanent residence status.
} 
Before considering some of the Canadian state's tactics of accumulation by dispossession, it is worth looking a little more closely at the mining industry, as it provides a fairly sharp example of the tensions between capitalist development and Indigenous self-determination just noted. Mining is a very important sector of the Canadian economy, representing approximately three percent of its GDP, and, as I noted at the beginning of this article, mining companies are key players in Canadian capital's expansion in the Americas. Over the last decade, mining companies have been expanding their activities into regions of the country where capitalist development has hitherto been limited. Exploration has been increasing in northern and interior British Columbia, the north of the prairies, Ontario and Quebec, the Yukon, Nunavut, and especially the Northwest Territories since diamond deposits were discovered there in the early 1990s. At the global level, Canada is now one of the top destinations for exploration capital, with the Northwest Territories, Ontario, Quebec and Nunavut attracting the largest share of investment over the last couple of years (exploration investment in the Northwest Territories, for instance, primarily for diamonds, was anticipated to have increased by $122 \%$ between 2003 and 2004). Canada has, in fact, the largest concentration of mining companies in the world operating within it, with interests in over 3,700 properties. Nevertheless, unlike in any other destination for mining investment, domestic companies have the largest stake in Canada's mining industry, perhaps not so surprising since Canadian companies now actually hold the largest share of the global exploration market (Malatest and Associates, 2004: 5-6, 20; Lemieux, 2003: 7.2).

As mining expands geographically in Canada, Indigenous land and labour has become absolutely central to the success of the industry. The Mining Association of Canada (1998: 2) notes that, " $[\mathrm{m}]$ ost mining activity occurs in northern and remote areas of the country, the principal areas of Aboriginal populations." Natural Resources Canada (2004: 2) reports, meanwhile, that approximately 1,200 Indigenous communities are located within 200 kilometers of an active mine, and this will only increase as exploration intensifies. The location of the majority of mining operations is significant, because it brings the industry squarely into conflict with Indigenous land rights, as First Nations claim much of the land mining companies seek to exploit, or oppose mining developments that will cause ecological damage to traditional territories and subsistence patterns (see for example, Mining Watch, 2005a, 2001; Alfred, 2001; Simmons, 1999). But the location of mines is also very significant in a context in which, as industry and government studies indicate, mining is facing a labour shortage (Malatest and Associates, 2004; Natural Resources Canada, 2004; Mining Association of Canada, 1998). Indigenous labour, in turn, is explicitly identified as central to the expansion of the industry. "Workforce diversity", as one industry-wide study expresses it, with a healthy dose of liberal veneer, is a necessity for mining (Malatest and Associates, 2004: 41). But not only will the mining industry and Indigenous communities benefit when Indigenous youth "acquire the skills and experience 
they need to meet the demands of the marketplace", Indian Affairs (Ministry of Indian Affairs and Northern Development, 2002b: 1) exclaims in an unabashed mobilization of nationalist sentiment, "the entire country ... benefits." The failure of Indigenous communities to submit to the capitalist market in general and to the mining industry in particular represents, then, a threat to the well being of the Canadian nation.

Indigenous communities, however, remain unsold on the 'benefits' of mining development and waged exploitation in mines, and opposition to mining remains strong. And so, not surprisingly, their resistance to the industry has become a focus of concern. The high value placed on a traditional 'lifestyle' - as if it is a fad Indigenous people have been slow to get over - which, one study laments with some degree of bewilderment, leads communities to resist wage work in spite of high unemployment on reserves, is now considered a 'challenge' to the industry and government, as is the persistent struggle in many communities against mining investment and the subsequent lack of an "efficient regulatory regime" facilitating companies' activities (Mining Association of Canada, 2005; 1998: 4; Malatest and Associates, 2004: 43). The mining industry and government have responded by developing promotional material aimed at selling mining and wage labour to Indigenous peoples as an opportunity for developing a strong economic base in rural communities, employing rhetoric about 'respect' for Indigenous culture, and promoting impact benefit agreements that supposedly make Indigenous concerns and rights central to new developments. But the carrot approach of warmly encouraging indigenous compliance with capitalism by extolling the benefits of development, has met with only limited success, and so the mining industry, together with capital more generally and the state, is engaging in more concerted measures to insure the expansion of capitalist relations in the north.

One of the principal means by which the state has sought to dispossess Indigenous people of their land is through the formal land claims process. The federal and provincial governments have established the land claims process as the legitimate legal avenue to settle outstanding territorial issues, although it has been framed in such a way as to make impossible a fair and timely settlement for Indigenous nations. When the framework is established by what are essentially colonial occupying governments and their legal system, without acknowledgement of the historic wrongs done to Indigenous people or that the latter never ceded their sovereignty to the crown, then there can be no pretense to equality between the participants - the colonized and the occupiers. The fact that it can take up to fifteen years or longer in the extremely bureaucratized federal land claims process before the first stage is even initiated after a claim has been made by an Indigenous nation expresses, furthermore, the commitment of the Canadian state to a fair settlement. That is essentially fifteen more years for corporations to expropriate and ecologically damage Indigenous territory, which is still officially crown land, with the government's consent, 
and for poverty and economic desperation in Indigenous communities to increase.

Writing on the British Columbia Treaty Commission (BCTC), Taiaiake Alfred (2001: 1) describes the treaty process as a failure for Indigenous nations and "at its core morally bankrupt" and "illegitimate." It is organized, he argues, with the purpose of promoting the state's colonial agenda and facilitating the penetration of Indigenous territory by resource companies. B.C., like other governments in Canada, was actually very reluctant to participate in any such process in the first place. Indigenous people were in fact prohibited under the Indian Act from organizing politically and raising money to hire lawyers and press claims until into the 1970s (Rynard, 2000: 215; Simmons, 1999), and B.C. itself did not recognize Indigenous land claims until the 1990s after a resurgence of Indigenous militancy. The aim of the treaty process has been to absorb serious political activity into the safer legal realm and bind Indigenous nations into legal arguments and maneuvering. But the central demand underlying governments' participation in the BCTC process, the extinguishment of Aboriginal title supposedly protected by section 35 of the Constitution Act, 1982 (involving the relinquishing by Indigenous nations of their political sovereignty and ownership over their lands to the Canadian government) in return for a small sum of cash and a fraction of their traditional territories, nevertheless makes clear the government's ultimate goal: to solidify the colonial control of Indigenous communities and land by denying Indigenous nationhood and the violent and illegitimate colonial basis upon which British Columbia and Canada were founded in the first place.

The two modern comprehensive treaties proudly signed by the Canadian government with the James Bay Cree and the Nisga'a - are based on the same colonial logic. Central to both is the extinguishment of Aboriginal title over most of the First Nations' traditional territories, providing corporations with access to their resources with the knowledge that the issue of title will never have to be revisited (the kind of 'predictable' and 'efficient' access called for in mining industry documents). It is estimated that the James Bay Cree only retained control over approximately one-and-a-half percent of their traditional land, and the Nisga'a between ten and twenty-five percent of theirs - small plots which critics suggest will make self-sufficiency extremely difficult, especially given the rate of population growth in Indigenous communities (Rynard, 2000: 225). Furthermore, the Nisga'a do not even have jurisdictional powers over the rivers and lakes in that ten to twenty-five percent, and under the agreement this land is held by fee simple title, meaning that their relationship to their land is now formally defined by the Canadian legal system. "Extinguishment", former Assembly of First Nations leader Matthew Coon Come remarks, "is brutal conquest attempted with a fountain pen", dispossessing Indigenous nations of their land and resources, and using the history of colonialism and desperation in their communities to impose such inequitable settlements (quoted in Rynard, 2000: 233). 
Rynard (2000: 220-221) highlights the Nisga'a agreement's important assertion that Aboriginal title is "continued as modified". Because Aboriginal rights are included in the Constitution Act, 1982, they cannot be extinguished with unilateral legislation, and so the clause in the Nisga'a agreement noting their modification is essentially designed as an end run around the constitution - a legal circumvention of Aboriginal rights as government policy of dispossession. But the government's authority to overstep Aboriginal rights when necessary is actually affirmed by the Supreme Court's 1997 Delmaguukw decision, which was derided by the political Right and the resource industry as a major legal coup for Indigenous people. Alfred (2001: 13), however, rightly describes the Delgamuukw decision "as a mere refinement of the logic of dispossession that has lain beneath Canadian policy for generations." While the decision affirms Aboriginal title to be a right to the exclusive use and occupation of land protected by section 35 of the Constitution Act, 1982 - the part of the decision publicly focused on by the political Right and the resource industry - it also stresses that that title is not absolute and can be infringed upon. In his majority opinion, Chief Justice Lamar argues that, "the development of agriculture, forestry, mining, and hydroelectric power, the general economic development of the interior of British Columbia, protection of the environment or endangered species, the building of infrastructure and the settlement of foreign populations to support those aims, are the kinds of objectives that ... can justify infringement of aboriginal title (quoted in Alfred, 2001: 13)." At the same time, though, the Delmaguukw decision also makes it extremely difficult for Indigenous nations to prove title to traditional land in the first place - demanding proof of exclusive occupancy prior to British sovereignty on the territory in question and continuity of occupancy from then until now if present occupation is used as evidence - and, Dacks (2002: 244) argues, government officials are incorporating this fact into their negotiating strategy in their effort to undermine Indigenous rights by opposing title claims at every turn. This tough bargaining stance is complemented, furthermore, by policies which make it easy for resource companies to exploit Indigenous land. In B.C., for example, where the mining industry has been mounting an aggressive campaign for access to mineral deposits in the interior, the government recently introduced internet claim staking as part of its new mining plan (Mining Watch, 2005a). Companies can now claim land for exploration with the click of a mouse.

Thus the bourgeois legal realm provides a solid option for the state in its pursuit of an ultimately fraudulent and predatory expansion into Indigenous territory. While the legal arena is typically presented by Canadian (and some Indigenous) politicians, businesses, lawyers, and the media, as a neutral ground where the rights and responsibilities of the parties entering it can be weighed in a fair way by learned and impartial officials, at the end of the day it is an institutional feature of a colonial state, involving laws written and arbitrated by administrators and representatives of a colonial state, and ultimately presides over and sanctifies an occupation of nations most of whom never ceded their sovereignty 
to Canada. It was not designed, in other words, to defend Indigenous rights. Indeed, as noted earlier, even when agreements or treaties exist between Canada and Indigenous nations, Canada has more often reneged on them in one way or another than not. Treaty lands are constantly being whittled away by attrition by government and business, with little hope of redress for Indigenous people. Highway construction, golf course expansion, army bases, the tourist industry, housing developments, and resource exploitation, for instance, are constantly encroaching on Indigenous territories as Canada demonstrates it has no intention of allowing treaties to interfere with its economic development. A similar attitude frequently marks the federal and provincial governments' and corporations' consideration for the environmental assessments and impact benefit agreements they participate in with Indigenous communities prior to resource development. They are commonly used by corporations and governments in the north now to facilitate resource exploitation on Indigenous land with a façade of ecological and cultural sensitivity. Typically, however, input by Indigenous groups and scientific experts on their behalf in the review process is severely limited, and rights obtained by corporations in the agreements are fully exploited while those of Indigenous communities go unfulfilled (Mining Watch, 2001). Sham environmental assessments, one-sided comprehensive agreements, and ongoing appropriation of treaty land continue to strangle the possibility for self-sufficiency in Indigenous communities, making life for its members increasingly desperate, expressed in substance abuse, high suicide rates among Indigenous youth, and escalating migration to urban centres, which weakens their ability to defend traditional territories from further encroachments while adding to the pool of surplus labour in cities (Ministry of Indian Affairs and Northern Development, 1997a).

Desperation and migration are not the only Indigenous responses to the intensification of Canadian colonialism, however. The last fifteen years have also been witness to a renewal of Indigenous militancy, as direct conflict between Indigenous nations and state authorities has increased in response to the pressures of geographical expansion. The Canadian state's ability to impose unjust settlements on Indigenous nations and continue to parcel away their land is dependent on the balance of forces between them. The increasing resort by Indigenous communities to road blocks, occupations, and armed stand-offs like those at Oka, Gufstafsen Lake and Burnt Church, and the spread of the militant warrior movement, has limited the state's colonial ambition in some important instances (on the warrior movement, see Alfred and Lowe, 2005). But the state has not given up or reconsidered its policies. Instead, it has responded through militarization and the deployment of increasing levels of violence. The Suretée du Quebec (SQ) and the RCMP after the Mohawk and Gufstafsen Lake revolts respectively, for example, both increased their militarization considerably in preparation for future confrontations, and aggressive policing more generally has become an important part of state policy towards Indigenous frustrations with the long and unsatisfactory official lands claim process (Toronto Star, 1997: A12; 
Waganese, 1991: 4). ${ }^{9}$ When legal thievery is insufficient, in other words, the state will use brute force in its effort to steal land and force compliance with its agenda - no different than any other imperial power.

\section{Canada and Latin America}

Latin America has been an important site in the geographic expansion of global capitalism over the last two decades, and as I will show Canada is a significant part of a broader trend of increasing involvement in the region by advanced capitalist countries. As the developing world has been taking up an increasing share of global foreign direct investment (FDI), Latin America has become one of the principal destinations of investment from core nations, particularly its large resource sector. Latin America in fact experienced the highest rate of increase of FDI from the Global North for all developing regions in the 1990s (UNCTAD, 2004; ECLAC, 2003). Growth in investment in the resource sector has risen just as rapidly. It is estimated that the share of worldwide exploration investment in developing countries increased from thirty-five percent in 1990 to fifty-eight percent by 2001, and reached as high as sixty-seven percent in 1997 before the recession (World Bank, 2003). Mineral investment in Latin America quadrupled over the same period, and the region now receives twenty-nine percent of the global total (Campodónico and Ortiz, 2002).

The increase in investment in the region has followed the massive round of structural adjustments imposed on one country after another in it by the World Bank and International Monetary Fund (IMF) in the 1980s and 90s (Petras and Veltmeyer, 2002). Like elsewhere, structural adjustment has forced open the economies of the region to capital from the North and led to a massive wave of privatization, drastic cutting of public spending, and the transformation of collective lands into privately-owned property; and like elsewhere, Latin America has also witnessed a significant increase in landlessness, especially among Indigenous people in rural areas, as large numbers of direct producers have been displaced and forced to enter the growing pool of surplus labour waiting to be exploited by corporations from the North (see, for example, Hristov, 2005; Valle, 2003; Petras and Veltmeyer, 2002; Petras and Veltmeyer, 2001). The 'economically active population' - those people participating in the formal labour market - has risen steadily over the last two decades, according to the Economic Commission on Latin America and the Caribbean (1999), and will continue to do so for the next several decades, especially among women. As Valle (2003: 94) observes, “[b]y the 1990s the principal connection with the market for small-scale peasants occurred not through agricultural production but rather through urban migration and the sale of their labor."10 Similar to Canada,

\footnotetext{
${ }^{9}$ The killing of Dudley George - an unarmed protester from the Stony Point Band occupying unceded land in Southwestern Ontario confiscated by the government during the Second World War - in the fall of 1995 by the Ontario Provincial Police's (OPP) Tactical Response Unit is a tragic example of this. See Edwards (2003) for an investigative account of the killing and the community's struggle for a public inquiry, which was ultimately successful. The public inquiry, called by the newly-elected Ontario Liberal government in 2004, is still ongoing.
} 
Indigenous land throughout Latin America is increasingly in the sights of resource companies, while Indigenous people will make up a significant layer of the region's new proletariat over the next couple of decades if the World Bank and IMF have their way. Indigenous people represent ten percent of the population regionally, and much higher percentages in places like Bolivia, Ecuador and Peru, and their fertility rate is currently almost double that of the non-Indigenous population (ECLAC, 2004, 2000). Indigenous people already suffer the most from structural adjustment in a region where working people generally have fared very badly at the hands of the IMF and World Bank (Petras and Veltmeyer, 2001). The World Bank's (2005) own study of Indigenous people in the region acknowledges that since the 1990s they saw few gains in poverty reduction, in several countries are worse off today than they were a decade ago, face systemic discrimination by employers, and fare much worse on basic health indicators than nonIndigenous people.

One of the principal ways Canada establishes the conditions necessary to facilitate its own imperialist ambition in the region and appropriate Indigenous land has been, like other countries of the North, through its participation in international organizations like the World Bank and IMF. Canada, it needs to be stressed, plays a leading role in these institutions, and certainly was not forced into supporting their aggressive imposition of structural adjustment on poor countries. The Canadian government began supporting structural adjustment measures through the Bretton Woods institutions by the mid-1980s, and by the late $80 \mathrm{~s}$ structural adjustment was strongly endorsed by the Canadian International Development Agency (CIDA) and the departments of Finance and External Affairs as part of an effort to facilitate the expansion of Canadian economic interests in the wake of the crisis of the 1970s (Black and McKenna, 1995; Burdette, 1994; Pratt, 1994; Department of Foreign Affairs and International Trade, 1995).

This priority is just as strong today, though state officials seldom use the term 'structural adjustment' anymore, since it has become a very controversial policy, the cause of much unrest throughout the Global South, and the subject of sharp public criticism in advanced capitalist countries. Instead, Canada talks about 'poverty reduction', and refers to 'Poverty Reduction Growth Facility' (PRGF), the term that replaced 'structural adjustment' in IMF- and World Bank-speak. But the PRGF programs, and the IMF, World Bank and Canadian attitudes toward the developing world have not changed in any meaningful sense. In its Report on Operations Under the Bretton Woods Related Agreements Act, for instance, the government reiterates its support for structural adjustment, if through more guarded language. It emphasizes "macroeconomic stability" as the tool for poverty reduction, and notes that "much remains to be done to restore fiscal discipline in emerging markets ... a number of structural rigidities" still need to be addressed (Department of Foreign Affairs and International Trade and Finance, 2004). In

10 In Colombia, it is worth noting, displacement of Indigenous people, whose land is on top of the some of the country's richest mineral and oil deposits, is often the direct result of repression by paramilitaries linked to the government and multinational corporations (Hristov, 2005). 
a similar fashion, CIDA, in its 2002 policy statement, Canada Making a Difference in the World, suggests a "more balanced approach" to poverty reduction is important, but nevertheless stresses that "economic growth is a fundamental prerequisite for reducing poverty in the developing world," and this growth will not occur unless countries open themselves up to economies of the North and pursue the necessary economic restructuring (CIDA, 2002: 18). This sentiment is also echoed in the "Development" section of Canada's new International Policy Statement, released in the Spring of 2005 (Canada, 2005a). Its section on development, produced through CIDA, blames poverty on economic stagnation and offers the expansion of free market principles as the solution. And this despite CIDA's (CIDA, 2005) own acknowledgement that "trade liberalization and opening up to the global economy ... have contributed to growing inequality" in the Americas. Canada also boasts of its central role in the IMF's and World Bank's adoption of the Poverty Reduction Strategy Papers, which promotes the local ownership of the PRGF process, whereby recipient countries are encouraged to develop their own restructuring agendas (Department of Foreign Affairs and International Trade and Finance, 2004). However, even a study published by the IMF on the Strategy Papers argues that they have had no meaningful impact on the process, and states that the "actual achievements ... far fall short of potential" and "avoid addressing key strategic choices involving 'controversial' structural reforms (IMF, 2004: 3,4)." Canada's promotion of the Poverty Reduction Strategy Papers, then, is nothing more than an attempt to provide a new gloss to an old and much hated policy of structural adjustment.

Behind the Canadian state's continued support for structural adjustment is its desire to secure access for its direct investments in the Global South. The "Commerce" section of the new International Policy Statement highlights the importance to the health of the Canadian economy of Canadian firms spreading abroad and securing access to resources and infrastructure through direct investment. This aspiration for access to the resources, services and people of the South requires, though, a predictable and transparent set of economic rules to facilitate Canadian access to foreign economies. This can be achieved by "investment rules", which "offer a greater measure of security for Canadian investors and ensure that national policies will not be unduly changed or applied in a discriminatory manner" (Department of Foreign Affairs and International Trade, 2003: 1). The establishment of these investment rules is a key feature of Canada's free trade agreements with Chile and Costa Rica, its Trade and Investment Cooperation Agreements with the Andean countries and the Southern Cone common market (Mercosur), and its pursuit of free trade agreements with the Andean countries and Mercosur and of the Free Trade Area of the Americas (FTAA) (Department of Foreign Affairs, 2004, 2003a, 2003b). While these deals entrench investor rights, they include no meaningful protection for labour, environmental or Indigenous rights; and despite the existence of a number of international declarations on Indigenous rights, Canada has refused to sign them. 
The mining industry is also particularly clear about its goals for investment access in Latin America. Just as the World Bank has laid out its sharply neoliberal program for the mining industry in Latin America - calling attention to the problem of Indigenous people interfering with mine development (World Bank, 1996: 79), to the need for greater flexibility in labour markets (World Bank, 1996: 25), and to the importance of liberalizing investment rules by extending corporations' legal rights and guaranteeing them easier access to mineral deposits (World Bank, 2003: 11) - so too has the Canadian industry been pushing strongly for a more favourable climate for investors. Industry organizations, for instance, have denounced what they view as unfair barriers to accessing the region, including, apparently, environmental laws (Canadian Mining Industry, 1999: 3) and other regulations benefiting "special interests" (Mining Association of Canada, 1999: 3), and have been strong advocates for an FTAA that will establish a uniform "process for hemispheric investment", protecting the rights of Canadian companies (Mining Association of Canada, 1999: 4). The push by the likes of the World Bank and the Canadian mining industry, with the support of the Canadian state, for reform in Latin American mining sectors has been fairly successful, as resource-rich countries like Chile, Argentina, Bolivia, Peru and Colombia have adopted mining codes that unambiguously favour corporations over Indigenous people, the environment, and labour protections (Bastida, 2000). The most egregious example of this is perhaps in Colombia, where the mining code allows international capital to enter Indigenous territories containing mineral deposits unfettered, while Plan Colombia also "guarantees private sector control over natural resources, even if this means the forcible removal of the existing population from certain areas of the countryside" (Hristov, 2005: 110).

In this context, Canadian Foreign Direct Investment abroad, or Canadian Direct Investment (CDI), has - quite contrary to the dependency school's notion of Canada being overrun by foreign capital - increased sharply since the early 1990s, and Canada has actually been a net exporter of direct investment since 1997 (Industry Canada, 2004). By 2004 , the cumulative stock of CDI was $\$ 438.4$ billion, and the rate of increase of Canada's FDI abroad well outpaces other G-7 countries, while its ratio to GDP is above the Organization for Economic Cooperation and and Development (OECD - an organization of most advanced capitalist countries) average (Industry Canada, 2004). Similar to the FDI trend of advanced capitalist countries in general, furthermore, CDI is increasingly going to countries of the Global South. In the early 1950s, this region received approximately ten percent of total CDI, but by 2000 it received just over a quarter (Department of Foreign Affairs and International Trade, 2005). Of the top fifteen nation recipients of CDI in the Global South, nine are in Latin America and the Caribbean, and of the twenty fastest growing destinations of global CDI, twelve are in Latin America, particularly the resource-rich nations (Department of Foreign Affairs and International 
Trade, 2005). Canadian Direct Investment into non-NAFTA countries in the Americas increased, in fact, six-fold from 1990 to 2002, making Canada one of the largest investors in the region (Department of Foreign Affairs and International Trade, 2003b). From 1996 to 2003, Canada was the first of all countries in FDI in Ecuador, second in Argentina, third in Chile, and fourth in Colombia, all countries where natural resources are prominent in their respective FDI makeup (ECLAC, 2003). And, as suggested earlier, mining is an industry in which Canada has a very strong presence in the South. For instance, twentyseven percent of total CDI in developing countries is in energy and minerals, considerably higher than other advanced capitalist countries (Industry Canada, 2004; ECLAC, 2003). Much of this investment is directed at Latin America, as the Canadian industry has moved to gain control of some of the richest deposits in the world. Indeed, after Canada, Latin America has become the region of the world where Canadian companies are most active in mineral exploration (Lemieux, 2003). Five of the top six locations for Canadian mineral investments abroad are in Latin America and the Caribbean, with investments in approximately 1000 mineral properties there (Lemieux, 2003). By 2002, Canadian companies held more than twenty-seven percent of the larger company market in Latin America (Lemieux, 2003), with seven Canadian companies among the top twenty mineral exploration investors in the region from 1989 to 2001 (Campodónico and Ortiz, 2002).

Canada, in other words, is not a mere subordinate player in the global economy, and, with the support of the IMF, World Bank and trade and investment agreements, it is playing an increasingly prominent role in Latin America, especially in the resource sector (though it is also prominent in services and telecommunications). As Canadian involvement in this region grows, so too does the controversy around its companies' practices, especially as they relate to Indigenous people and the environment. Most of the large deposits Canadian mining companies seek to exploit in Latin America are on Indigenous land, requiring the displacement of communities, and mineral extraction is an extremely ecologically sensitive practice, particularly when environmental laws are lax or rarely enforced, which can destroy resources communities depend on for subsistence living. Canadian-based corporations like Manhattan Minerals, Barrick Gold, Glamis Gold, Corona and Ascendant Copper, among many others, are at the centre of fierce struggles pitting poor Indigenous communities against powerful corporations who are attempting to seize their land and threaten their ecological sustainability as they expand in Latin America; and these corporations have proven willing to use whatever measures necessary to ensure they get their way, including de-frauding people of their land, ignoring local referendums calling for a halt to their operations, and, in Colombia and Guatemala at least, enjoying the support of local militaries and paramilitaries who have assassinated their Indigenous opponents and union activists (Mining Watch, 2005b; Quilumbgango, Saul and Kuyek, 2005; Mining Watch, 2004; Clark, 2003; Isla, 2002; see also the Subcommittee on Human Rights and International Development, 2005). ${ }^{11}$

\footnotetext{
${ }^{11}$ Corona, for example, is implicated in the killing of 500 people in Colombia.
} 


\section{Conclusion}

Canada is much more than a rich dependency or mere subordinate nation overrun by foreign capital, whose influence on the global order is negligible if not benign. Canada is a capitalist power, whose political and economic interests are rapidly expanding: from the Northwest Territories to Colombia, from the interior of British Columbia to Ecuador, it is engaged in a systematic agenda of accumulation by dispossession, intensifying and extending its centuries long displacement of Indigenous people and subordination of the colonized to its whim. While Indigenous nations are not the only targets of this agenda, they are nevertheless central to it - a centrality that simply cannot be ignored if we look seriously at the development of Canadian capitalism and state power over the last 150 years. Indeed, focusing on Indigenous people highlights quite sharply the internal relationship between the long history of colonization in Canada and the latter's colonial interests abroad: the increasing involvement in Latin America, for instance, reflects an historical and geographical continuity of the imperialist project that defines the Canadian state and which began within its current borders against the country's First Nations.

The strategies by which Canada pursues its imperialist goals are, not surprisingly, not exactly the same at home as they are abroad. But there are general patterns common to both. International trade and investment agreements, structural adjustment programs, and the land claims process framed by one-sided Supreme Court rulings, for example, are all strategies exploiting economic weaknesses and designed to circumvent Indigenous rights by providing capital with predictable and efficient access, entrenched in law, to their land. Both at home and abroad, however, the legalistic approach is backed up always with violence. Simply because Canada cannot mobilize an army of the size and force of the U.S.'s, or marshal the same kind of resources to fund proxies on the same scale as the U.S., in order to impose its imperial agenda, does not mean it never engages in such practices. Recent events in Haiti, Guatemala, Colombia and Ipperwash prove otherwise.

The Canadian state's recourse to force to defend its imperial agenda implies that its activities at home and abroad also have one other very important feature in common - the resistance that marks the limits to the geographical expansion of Canadian capital, as people seldom willingly submit to IMF-dictate or the thievery that is the official land claims or impact benefits process. And this resistance, furthermore, is likely to increase in the future as the pressures Canadian expansion puts on communities and their land intensify. At the same time, this dynamic at the heart of the Canadian state project Canada's colonial aspirations coming face-to-face with anti-imperial struggle - poses a serious challenge for Canadian activists and the Canadian political-economy literature. The resistance demands our solidarity, while forcing us to seriously reconsider Canada's role in the world. Time will tell if we are up to the challenge. 


\section{REFERENCES}

Adams, H. 1999. Tortured people: The Politics of Colonization. Revised Edition. Penticton: Theytus Books.

Adams, H. 1989. Prison of Grass: Canada From and Native Point of View. Saskatoon: Fifth House.

Alfred, T. 2001. "Deconstructing the British Columbia Treaty Process." www.taiaiake.com.

Alfred, T \& L. Lowe. 2005. "Warrior Societies in Contemporary Indigenous Communities." www.ipperwashinquiry.ca.

Bastida, E. 2000. "A Review of the Concept of Security of Mineral Tenure: Issues and Challenges." Centre for Energy, Petroleum and Mineral Law Policy. Vol. 17, Article 7. www.dundee.ac.uk/cepmlp/journal.

Black, D. and P. McKenna. 1995. "Canada and Structural Adjustment in the South: The Significance of the Guyana Case." Canadian Journal of Development Studies. Vol. 16, No. 1, pp. 55-78.

Bonefeld, W. 1993. The Recomposition of the British State During the 1980s. Aldershot: Dartmouth.

Burdette, M. 1994. "Structural Adjustment and Canadian Aid Policy." In Canadian International Development Assistance Policies: An Appraisal. C. Pratt (ed.). Kingston: McGill-Queen's University Press, pp. 210-239.

Campodónico, H. \& G. Ortiz. 2002. Caracteristcas de la inversion y del mercado mundial de la mineria principios de la decade 2000. Chile: ECLAC.

Canada. 2005. International Policy Statement: A Role of Pride and Influence in the World. Development. Ottawa: CIDA.

Canadian International Development Agency. 2005. "A Strategy for CIDA in the Americas." www.acdi-cida.gc.ca. 
Canadian International Development Agency. 2002. Canada Making a Difference in the World: A Policy Statement on Strengthening Aid and Effectiveness. Ottawa: CIDA.

Canadian Mining Industry. 1999. "Escalating Market Access Concerns and Economic Implications for the Canadian Minerals and Metals Industry.” Brief to the 1999 Mines Ministers Conference. Charlottetown. September 13. www.mining.ca.

Clark, T. 2003. "Canadian Mining Companies in Latin America: Community Rights and Corporate Responsibility." Centre for Research on Latin America and the Caribbean conference report. May 9-11, 2002. York University, Toronto.

Dacks, G. 2002. "British Columbia After the Delgamuukw Decision: Land Claims and Other Processes.” Canadian Public Policy. Vol. 28, No. 2, pp. 239-255.

Department of Foreign Affairs and International Trade. 2005. Sixth Annual Report on Canada's State of Trade. Ottawa: Minister of Public Works and Government Services.

Department of Foreign Affairs and International Trade. 2004. Opening Doors to the World: Canada's International Market Access Priorities, 2004. www.dfiat-maeci.gc.ca.

Department of Foreign Affairs and International Trade. 2003a. Opening Doors to the World: Canada's International Market Access Priorities, 2003. www.dfait-maeci.gc.ca.

Department of Foreign Affairs and International Trade. 2003b. "FTAA Draft Text, Canada's Positions and Proposals, and Frequently Asked Questions." www.dfait-maeci.gc.ca.

Department of Foreign Affairs and International Trade and Department of Finance. 2004. Report on Operations Under the Bretton Woods Related Agreements Act. Ottawa: International Trade and Finance Branch.

Dolan, C. 2004. “'I Sell My Labour Now': Gender and Livelihood Diversification in Uganda." Canadian Journal of Development Studies. Vol. 25, No. 4, pp. 643661.

Economic Commission for Latin American and the Caribbean. 2004. Social Panorama of Latin America. Washington: ECLAC. 
Economic Commission for Latin American and the Caribbean. 2003. Foreign Investment in Latin America and the Caribbean. Chile: ECLAC.

Economic Commission for Latin American and the Caribbean. 2000. Etnicidad, Raza ' $y$ Equidad en America Latinay el Caribe. Chile: ECLAC.

Economic Commission for Latin American and the Caribbean. 1999. Latin America: Economically Active Population. Chile: ECLAC.

Edwards, P. 2003. One Dead Indian: The Premier, The Police and the Ipperwash Crisis. Toronto: Stoddart.

Engler, Y. \& A. Fenton. 2005. Canada in Haiti. Halifax: Fernwood.

Elias, P. 1988. The Dakota of the Canadian Northwest: Lessons in Survival. Winnipeg: University of Manitoba Press.

Gowan, P. 1999. The Global Gamble: Washington's Faustian Bid for World Dominance. London: Verso.

Hall, A. 2003. The American Empire and the Fourth World. The Bowl With One Spoon. Part One. Montreal: McGill-Queen's University Press.

Harvey, D. 2003. “The 'New' Imperialism: Accumulation By Dispossession.” Socialist Register. L. Panitch and C. Leys (eds.). Halifax: Fernwood, pp. 63-88.

Harvey, D. 1999. The Limits to Capital. London: Verso.

High, S. 1996. "Native Wage Labour and Independent Commodity Production During the 'Era of Irrelevance'.” Labour/Le Travail, Vol. 37, Spring, pp. 243-264.

Hristov, J. 2005. "Indigenous Struggles for Land and Culture in Cauca, Colombia." Journal of Peasant Studies. Vol. 32, No. 1, pp. 88-117.

Industry Canada. 2004. Trade and Investment Monitor. Ottawa: Industry Canada, Microeconomic Policy Analysis Branch.

International Monetary Fund. 2004. Evaluation of the IMF's Role in Poverty Reduction Strategy Papers and Poverty Reduction Growth Facility. Washington: IMF. 
Isla, A. 2002. "A struggle for clean water and livelihood: Canadian mining in Costa Rica in the era of globalization." Canadian Woman Studies. Vol. 21, No. 4, pp. 148154.

Knight, R. 1996. Indians at Work: An Informal History of Native Labour in British Columbia 1858-1930. Vancouver: New Star Books.

Laliberte, R. \& V. Satzewich. 1999. "Native migrant labour in the southern Alberta sugarbeet industry: coercion and paternalism in the recruitment of labour." Canadian Review of Sociology and Anthropology. Vol. 36, No. 1, pp. 65-85.

Lemieux, A. 2003. “Canada's Global Mining Presence.” In Canadian Mineral Yearbook, 2002. Natural Resources Canada. Ottawa: Minerals and Metals Sector.

Malatest \& Associates Ltd. 2004. A Situational Analysis of the Minerals and Metals Industry. Report prepared for the Minerals and Metals Industry Sector Study Steering Committee.

Marx, K. 1995. The Communist Manifesto. New York: International.

McNally, D. 2002. Another World is Possible. Winnipeg: Arbeiter.

Mining Association of Canada. 2005. Annual Report. Human Resources Committee. www.mining.ca.

Mining Association of Canada. 1999. "Study on the Free Trade Agreement of the Americas (FTAA)." A submission to the House of Commons Standing Committee on Foreign Affairs and International Trade. May 11. www.mining.ca.

Mining Association of Canada. 1998. "Aboriginal Economic Development and the Canadian Mining Industry." Presentation to the Standing Committee on Aboriginal Affairs and Northern Development. June 10. www.mining.ca/english/publications/native.html.

Mining Watch. 2005a. "Assault on First Nation Lands in British Columbia. www.miningwatch.ca.

Mining Watch. 2005b. "Failure to Disclose Material Risk.” www.miningwatch.ca.

Mining Watch. 2004. "Urgent Environmental Alert: Protect the Glaciers of the South of the World!: Barrick Gold's Pascua Lama Project.” www.miningwatch.ca. 
Mining Watch. 2001. "Mining in Remote Areas: Issues and Impacts." www.miningwatch.ca.

Ministry of Indian Affairs and Northern Development. 2002a. Economic Development in Ontario's First Nation Communities. www.ainc-inac.gc.ca.

Ministry of Indian Affairs and Northern Development. 2002b. Quebec First Nations: Our Economy, Our Future. www.ainc-inac.gc.ca.

Ministry of Indian Affairs and Northern Development. 2001. Aboriginal Labour Force Characteristics from the 1996 Census. Ottawa: Statistics Canada.

Ministry of Indian Affairs and Northern Development. 1997a. Implications of First Nations Demography. www.ainc-inac.gc.ca.

Ministry of Indian Affairs and Northern Development. 1997b. Gathering Strength:Canada's Aboriginal Action Plan. www.ainc-inac.gc.ca.

Ministry of Industry. 2003. Report on the Demographic Stituation in Canada, 2002. Ottawa: Ministry of Industry and Statistics Canada.

Natural Resources Canada. 2004. Mines and Minerals Sector: Sector Priorities for 20042006. Ottawa: Ministry of Public Works and Government Services.

Peters, E. \& M. Rosenberg. 1995. "Labour Force Attachment and Regional Development for Native peoples: Theoretical and Methodological Issues." Canadian Journal of Regional Science. Vol. 28, No. 1, pp. 77-105.

Petras, J. \& H. Veltmeyer. 2002. "The Peasantry and the State in Latin America: A Troubled Past, an Uncertain Future.” Journal of Peasant Studies. Vol. 29, No. 3, pp. 41-82.

Petras, J. \& H. Veltmeyer. 2001. Globalization Unmasked. Halifax: Fernwood.

Pratt, C. 1994. "Humane Internationalism and Canadian Development Assistance Policies." In Canadian International Development Assistance Policies: An Appraisal. C. Pratt (ed.). Kingston: McGill-Queen's University Press, pp. 334370 . 
Quilumbango, S., Saul, G. \& J. Kuyek. 2005. Letter to Mr. Vernon McKay, Canada's National Contact Point for the OECD Guidelines for Multinational Enterprises. May 16. www.miningwatch.ca.

Rynard, P. 2000. “'Welcome In, But Check Your Rights at the Door': The James Bay and Nisga'a Agreements in Canada." Canadian Journal of Political Science. Vol. 33, No. 2, pp. 211-243.

Satzewich, V. \& T. Wotherspoon. 1993. First Nations: Race, Class and Gender Relations, Scarborough: Nelson.

Simmons, D. 1999. "After Chiapas: Aboriginal Land and Resistance in the New North America." The Canadian Journal of Native Studies. Vol. 19, No. 1, pp. 119-149.

Subcommittee on Human Rights and International Development of the Standing Committee on Foreign Affairs and International Trade. 2005. Third Report to Committee. First Session, 38th Parliament.

Stasiulis, D. \& R. Jhappan. 1995. "The Fractious Politics of a Settler Society: Canada." Unsettling Settler Societies: articulations of gender, race, ethnicity and class. D. Stasiulis and N. Yuval-Davis (eds.). London: Sage, pp. 95-131.

Teillet, J. 2005. "The Role of the Natural Resources Regulatory Regime in Aboriginal Rights Disputes in Ontario." www.ipperwashinquiry.ca.

Toronto Star 1997. "RCMP wants armoured column of its own." Toronto Star. July 10, A12.

United Nations Conference on Trade and Development. 2004. World Investment Report, 2004. New York: United Nations.

Valle, L.M. 2003. "Endogenous Peasant Responses to Structural Adjustment.” In Rural Progress, Rural Decay: Neoliberal Adjustment Policies and Local Initiatives. L. North and J. Cameron (eds.). Bloomfield: Kumarian Press, pp. 85-105.

Waganese, R. 1991. “SQ Rambos On.”Windspeaker. Vol. 8, No. 22, p. 4.

World Bank. 2005. Indigenous Peoples, Poverty and Human Development in Latin America: 1994-2004. Washington: World Bank. 
World Bank. 2003. Mining Reform and the World Bank: Providing a Policy Framework for Development. Washington: World Bank.

World Bank. 1996. A Mining Strategy for Latin America and the Caribbean. Washington: World Bank. 